\title{
Globalization, FDI and Modernising Management Practices $^{*}$
}

Csaba Makó, Marc Ellingstad ${ }^{* *}$

This article deals with the role of Foreign Direct Investment in connection with the globalization process. Two sets of changes are taking place worldwide. First: the increasingly common expectations of investors, managers, and even consumers in countries and regions with widely varied economic and cultural histories as a result of FDI. Second: This change is harder to grasp. It is the reaction to the first change and the religion of uniform global capitalism which is being questioned and challenged.

This paper is aimed to provide perspectives on various possibilities and limitations of FDI to serve as the engine of modernisation in the Hungarian economy.

In diesem Artikel wird die Rolle des Foreign Direct Investment (FDI) in Verbindung mit dem Prozess der Globalisierung diskutiert. Weltweit zeigen sich dabei zwei Veränderungen. Erstens: Hier geht es um die in immer größerem Maße gemeinsamen Erwartungen an FDI von Investoren, Managern und sogar Konsumenten in Ländern mit verschiedensten ökonomischen und kulturellen Hintergründen. Zweitens, und diese Veränderung ist schwieriger zu erfassen: Die Reaktion auf die erste Veränderung ist eine Infragestellung der weltweiten Gleichartigkeit des Kapitalismus.

Es wird in dieser Arbeit versucht, verschiedene Perspektiven und Grenzen von FDI aufzuzeigen, die als Antrieb für die Modernisierung der ungarischen Wirtschaft dienen.

\footnotetext{
* manuscript received: 15.12.1999, accepted: 21.02.2000;

** Institute of Sociology, Hungarian Academy of Sciences, Budapest;
} 


\section{Introduction: Rethinking the Inevitability of Globalization}

Today's global economy is going through two sets of great changes. The first has been extremely rapid but incremental: the increasingly common expectations of investors, managers, and even consumers in countries and regions with widely varied economic and cultural histories. The forces driving this phenomenon have been the impulse to open new markets or to produce goods cheaper for traditional markets on the supply side of the equation, and new, world-wide media and advertising on the demand side. (These days, it is said, we are almost all watching the same TV shows, the same movies, the same advertisements). The mechanism used is Foreign Direct Investment (FDI), which injects capital, a certain amount of managerial and technical know-how, and a certain amount of forced change into a foreign environment.

The second great change recently occurring is more exceptional and less easy to predict: it is the reaction to the first change and the religion of uniform global capitalism. We now see in Russia and in a number of countries in South East Asia substantial questioning of whether the one path is indeed right for all. This is the result of the massive failure of market reforms and private investments alone to secure the minimum that is required for social peace and order. Much of this failure, especially in Russia, is the result of native institutions repudiating the expectations that international capital brought with it, much as the human body can occasionally reject a transplanted organ.

A number of important lessons learned can be culled from the painful and costly social and economic experimentation performed on Russian society over the past years. First, the faith which conventional economists such as Jeffery Sachs, Anders Aslund, and the entire cabal of multilateral lenders placed on the ability of isolated islands of modern, market-oriented economic activity to reform and "reincentivize" other parts of society was clearly exaggerated. There was no shortage of mobile telephones and excitement for playing the bourse, and yet vitally important areas such as rule of law and tax collection could not even begin to keep pace with the more superficial changes.

Secondly, the more simplistic variants of the convergence theory of capitalist development, promulgated so heavily recently, seem to have missed the mark with a vengeance. Russia failed to achieve the benefits of the Polish model, which was prescribed for it throughout the 1990's by any number of \$2000/day western consultants.

The financial and social crisis in Russia speaks to our lack of understanding the ability or desire of indigenous actors and institutions to adapt fundamental change on the macro level. Relying solely on the macro level, we would not be able to begin to explain why the transformation processes in Central and Eastern Europe (CEE) have been judged to be more or less successful, while the Russian 
variant has been proven a painful failure, except for utilising vague cultural explanations.

To gain a deeper understanding of the transformation process, we feel that a focus on the firm-level and an examination of Foreign Direct Investment in particular, holds the most promise in revealing prospects - and potential indigenous barriers - of the adaptation of modern, international systems. In this paper, we utilise the CEE region, and Hungary in particular, as a case study to demonstrate some of the possibilities and limitations of FDI to serve as engines of growth and modernisation.

\section{Foreign Direct Investments: Short Overview and Hypothesis}

A large number of approaches to the globalisation process can be distinguished. However, almost all of these views could be located on the scale where the one extreme point is represented by the dominance of global corporations (Multinational Corporations, or MNCs) while the other extreme of the scale is occupied by firms whose key activities are concentrated in their country of origin. A more realistic approach treats "... globalization as multi-faceted and continuing, not an outcome; the process is advanced in some facets, and retarded in others. This globalization process is countered by a contrary process of fragmentation and localization ..." (Martin, 1998: 9)

When Porter (1990) in his well known book on the competitiveness of national economies intended to explain specific national features of competitive advantage, he in reality included several examples showing how successful industrial sectors were actually regionally embedded. As the authors of a recent EU Report on Regional Innovation System noticed in regards to his work: "What is now termed 'new regional science' recognizes this and has demonstrated the growing salience of regional economies as key nodes in the increasingly globalized arena of production". (Cooke-Boekholt-Tödtling, 1998:2)

The transformation-related modernisation in the post-socialist countries of Central and Eastern Europe (CEE) would be unimaginable without significant FDI and the related privatisation efforts - in spite of the occasional anti-foreign rhetoric of the populist-nationalist forces in these countries. For instance, in the Hungarian case, foreign-owned firms are now producing more than 70 per cent of manufactured exports, up from 50 per cent in 1993. The strongest labour productivity increases experienced in the last five years have been at foreignowned joint ventures (Hámori, 1996:10.)

There is a commonly shared hypothesis among business scientists (SoulsbyClark, 1996.) that among the foreign-owned firms, MNCs are playing the key role in modernizing managerial organization and methods of the privatized former large state firms. Moreover, these firms have become not only the 
"engines" of export performance but have also accelerated the introduction of new technology and of new managerial practices in the post-socialist economies (e.g., TQM, team-working, flat-hierarchy, outsourcing, benchmarking, etc.). Due to the important facilitator role of FDI in shaping the patterns of skill and manpower use, it is worthwhile offering a short survey of FDI in the CEE region.

Among the post-socialist countries of Central and Eastern Europe, Hungary received the largest portion of the FDI until the middle of 1996, with its share representing $\$ 15.1$ billion. The composition of FDI within the country is very unequally distributed however, which further strengthens the existing inequalities in Hungary. If we are using a three-point scale to characterise the level of economic development, the following three types of regions can be distinguished:
a. Strong regions
b. Intermediary regions
c. Weak or peripheral regions.

The so-called 'strong-regions' (e.g., the agglomeration of Hungarian capital and the western regions) received almost as much as three quarters (73.5 per cent) of the country's FDI. The 'intermediary region' (e.g., the Great Hungarian Plain in the Southeast) and the 'weak and peripheral' regions (e.g., Northeast Hungary and the southern portion of western Hungary) have similar share (13 - 13.5 per cent) of FDI. (Cséfalvay, 1993.) Since the middle of 1990's, this pattern of FDI distribution in the country has remained largely the same.

Table 1: FDI in the CEE Region

\begin{tabular}{|l|c|c|}
\hline Countries & 1995 & 1996 \\
\hline & \multicolumn{2}{|c|}{ in USD per capita } \\
\hline Czech Republic & 563 & 660.19 \\
\hline Hungary & 1.410 & 1.505 \\
\hline Poland & 177 & 240.21 \\
\hline Slovakia & 138 & 369.81 \\
\hline
\end{tabular}

Source: Business Central Europe, 1996: 39., Árva, L. 1997: 1008.

Within the broad range of FDI, it is necessary to distinguish between the investments into 'greenfield' versus 'brownfield' sites. Greenfield investments were carried out by such internationally well-known firms as Suzuki, IBM, TDK, Sony, Ford, etc. Brownfield investments were carried out by such multinational firms as NOKIA, Siemens, G.E., Audi, etc. These two distinctive 
forms of FDI have different impact on the restructuring or modernizing business organizations in the transformation economies of the CEE region.

Greenfield investment has attracted by far the most attention from both the business and academic observers. However, according to our hypothesis, a more balanced distribution of greenfield and brownfield investments represent a greater potential to speed-up the diffusion of modern managerial knowledge and organization. In other words, the diffusion of new technology and leading-edge management practices will create stronger multiplier or homogenizing effects in organizing economic activities in comparison to domination one form over another. In other words, the strong presence of foreign owned firms, especially in the form of greenfield sites, does not automatically significantly speed up the diffusion of state of art technology and management methods in the FDI receiving country.

(The role of FDI in upgrading quality level of products, services and management is significant not only in the transformation economies of the CEE but also in the countries belonging to the matured market economies. According to the study made by McKinsey, the US management consultant firm, more than two-thirds of UK suppliers, 44 per cent of US suppliers and 85 per cent of Japanese suppliers received his high evaluation of quality. Top management in the UK car component industry "has ... devoted itself intensely to quality, more than that of any other country in Europe", says the report. According to the McKinsey, the driving force behind the change in Britain has been the influence of car plants set up by Japanese groups. They have made "upping quality level ... a matter of survival for British suppliers", says the report of the US management consulting firm.) (Marsh, 1996.)

In the following sections, we intend to verify - among other things - the involvement of the Hungarian economy in the globalization process and to outline the potentials of modernising management and technology of the country. Empirical data analysed were collected from a survey carried out in one of the strong regions of the country (Székesfehérvár), where the amount of FDI (in the form of 'direct capital investment) surpassed 1 billion USD. This city in the first half of the 1990's became one of the most dynamic in the world in terms of its transformation from heavy industrial crisis to prosperious local economy.

\section{The Role of Strong Regions in Reorganizing Economic Activities: The Case of Székesfehérvár}

The core interest of the EU supported "Regional Innovation System" (REGIS) project was to identify the existence or lack of existence of the regional innovation system in eleven European regions. In this section we intend to present the results of the Hungarian survey connected to the role of FDI. The 
firm level interviews were conducted at 75 firms in the Székesfehérvár region, using standardized questionnaire elaborated and accepted by the all REGIS Project participants. The categories for the data analysis were selected on the basis of ownership structure (private ownership, joint-private/state ownership, and state-ownership), on the basis of firm age (greenfield sites and brownfield sites), and on the basis of nationality of ownership (domestically-owned and foreign-owned firms). Table 2 illustrates the breakdown of the categories which will be used for comparison.

Table 2: Categories utilized for Comparison

\begin{tabular}{|l|c|c|c|}
\hline Hungarian Firms & \% of total & $\begin{array}{c}\text { \% in Hungarian } \\
\text { category }\end{array}$ & N= \\
\hline Privately owned & 41.3 & 63.3 & 31 \\
\hline Private/State ownership & 10.7 & 16.3 & 8 \\
\hline State owned & 12.0 & 18.3 & 9 \\
\hline Greenfield site & 12.7 & 19.1 & 9 \\
\hline Brownfield site & 53.5 & 80.9 & 38 \\
\hline Total & 64.5 & & 49 \\
\hline Foreign Firms & \% of total & \% in Foreign category & \\
\hline Greenfield site & 28.2 & 83.0 & 20 \\
\hline Brownfield site & 5.6 & 16.7 & 4 \\
\hline Total & 35.5 & & 26 \\
\hline
\end{tabular}

Source: Makó-Ellingstad-Kuczi, T. 1997: 2.

In our analysis, foreign firms are considered those being in majority foreign ownership. Greenfield sites are considered those which did not exist in 1990. (Please note that for the Foreign-Brownfield site category the sample is so small as to provide only a very limited usefulness in statistical analysis, and therefore, we shall be concentrating on results from this category. Missing data prevented the proper greenfield versus brownfield sites categorization of two Hungarian firms, as well as two foreign-owned firms. The results from these firms will be examined only in the broader national categories)

The sample is representative of the Székesfehérvár region, where the vast majority of FDI has been directed not on privatization projects (acquisition of the formerly state-owned companies) but rather on greenfield manufacturing sites. The region - which once was the home of such flagship socialist firms as Videoton in computer and consumer electronics, Ikarus the bus manufacturer, etc. - has a well-trained, inexpensive work-force, a relatively well-developed 
infrastructure, and a variety of local and national investment incentives (including five and ten years tax holidays on profits, no local taxes for five years, etc.). These incentives have attracted such leading-edge firms as Ford, IBM, Phillips, etc., which tend to concentrate their local activities on assembly line operations. (Note: ten years later, these very generous local incentives for foreign-owned firms did create new type of conflicts between the subsidiaries of MNCs and the local governments, after the generosity of the local councils nearly bankrupt them. The current disputes have centered on the calculation bases of the local taxes.) ( Tóth, 1998: 30.)

\subsection{Strengths and Challenges of the Firms Operating in the Region}

Most firms surveyed were relatively optimistic and gave themselves high marks concerned their advantages over the competitors. Quality ( 91.7 per cent), timely delivery (89.6 percent), and price (87.5 per cent) were listed as the top three advantages by Hungarian firms, with state-owned firms giving themselves generally lower scores. Hungarian firms also rated those three factors as the most important, with user-friendliness, environmentally friendly production methods and after-sales services being judged the least important.

Foreign-owned firms top-listed advantages were quality (96.3 per cent), aftersales service (85.2 per cent), and technical standard/innovation ( 81.5 per cent). These firms rated quality, technical standards and after sales service as the most important factors, with user friendliness and an ecological environment being judged the least important.

When asked how their firms sustain competitive advantage, noticeable differences were noted between Hungarian and foreign-owned firms on issues relating to innovation. Internal research and development activities were given as a reason for competitive advantages by 62.5 per cent at foreign-owned firms, compared to only 45.8 per cent at Hungarian-owned firms. Similarly, patentownership was given as a reason 62.5 per cent of foreign firms versus only 35.4 per cent for Hungarian firms. As shall be discussed in more detail later, these differences can not be solely accounted for on the basis of on-site research and development, but rather, company-wide research and development. Larger, international corporations are able to garner more advantageous economies of scale in research and development than smaller domestic companies, and this phenomena is by no means limited to Hungary. (Cooke, 1998.)

Therefore, for smaller, domestic firms collaborative research undertakings may be especially important as a way to lower initial costs and share risks. In this respect, however, perhaps surprisingly given an intuitively greater need, Hungarian-owned companies seem less active than their foreign-owned counterparts. The latter category reports stronger scores not only in cooperation with EU institutions (50.0 per cent to 29.9 per cent), but also in national (62.5 per cent to 55.3 per cent) and regional ( 54.2 per cent to 43.8 per cent) co- 
operative ventures. Hungarian-owned companies also rate cooperative agreements, generically and in the regional, national and international contexts, as less important than do foreign-owned companies.

Table 3: Company's Responses to the Challenges

\begin{tabular}{|c|c|c|c|c|c|c|c|c|}
\hline & $\begin{array}{c}\text { Cutting } \\
\text { cost }\end{array}$ & $\begin{array}{c}\text { Org. } \\
\text { Restruc- } \\
\text { turing }\end{array}$ & $\begin{array}{c}\text { Speeding } \\
\text { up prod. } \\
\text { dev. }\end{array}$ & $\begin{array}{c}\text { Intens. } \\
\text { internal } \\
\text { R\&D }\end{array}$ & $\begin{array}{l}\text { Out- } \\
\text { sour- } \\
\text { cing }\end{array}$ & $\begin{array}{l}\text { Subcon- } \\
\text { tracting }\end{array}$ & $\begin{array}{l}\text { Marketing } \\
\text { cooperation }\end{array}$ & $\begin{array}{c}\mathbf{R} \& D \\
\text { cooper. }\end{array}$ \\
\hline \multicolumn{9}{|c|}{ Hungarian firms } \\
\hline $\begin{array}{l}\text { Privately } \\
\text { owned }\end{array}$ & $93.5 \%$ & $74.2 \%$ & $54.8 \%$ & $61.3 \%$ & $25.8 \%$ & $38.7 \%$ & $61.3 \%$ & $35.5 \%$ \\
\hline $\begin{array}{l}\text { Private/Stat } \\
\text { e ownership }\end{array}$ & $87.5 \%$ & $87.5 \%$ & $50.0 \%$ & $62.5 \%$ & $37.5 \%$ & $12.5 \%$ & $75.0 \%$ & $37.5 \%$ \\
\hline State owned & $100.0 \%$ & $88.9 \%$ & $55.6 \%$ & $55.6 \%$ & $55.6 \%$ & $33.3 \%$ & $55.6 \%$ & $55.6 \%$ \\
\hline $\begin{array}{l}\text { Greenfield } \\
\text { site }\end{array}$ & $100.0 \%$ & $66.7 \%$ & $33.3 \%$ & $66.7 \%$ & $22.2 \%$ & $22.2 \%$ & $44.4 \%$ & $22.2 \%$ \\
\hline $\begin{array}{l}\text { Brownfield } \\
\text { site }\end{array}$ & $92.5 \%$ & $82.5 \%$ & $60.0 \%$ & $60.0 \%$ & $37.5 \%$ & $37.5 \%$ & $67.5 \%$ & $45.0 \%$ \\
\hline Total & $93.9 \%$ & $79.6 \%$ & $55.1 \%$ & $61.2 \%$ & $34.7 \%$ & $34.7 \%$ & $63.3 \%$ & $40.8 \%$ \\
\hline \multicolumn{9}{|c|}{ Foreign firms } \\
\hline $\begin{array}{l}\text { Greenfield } \\
\text { site }\end{array}$ & $100.0 \%$ & $84.2 \%$ & $73.7 \%$ & $57.9 \%$ & $52.6 \%$ & $42.1 \%$ & $52.6 \%$ & $52.6 \%$ \\
\hline $\begin{array}{l}\text { Brownfield } \\
\text { site }\end{array}$ & $100.0 \%$ & $75.0 \%$ & $75.0 \%$ & $25.0 \%$ & $25.0 \%$ & $0.0 \%$ & $25.0 \%$ & $25.0 \%$ \\
\hline Total & $100.0 \%$ & $83.3 \%$ & $75.0 \%$ & $54.2 \%$ & $50.0 \%$ & $37.5 \%$ & $50.0 \%$ & $50.0 \%$ \\
\hline
\end{tabular}

Source: Makó-Ellingstad-Kuczi, 1997:12.

Managers were also asked what challenges they see their firms facing. Responses reveal that foreign-owned firms are slightly more pro-active, especially in regards to improving product quality, cutting personnel costs and product development. Averaging the scores for all possible challenges, foreignowned firms responded in the affirmative 86.3 per cent, compared to 76.7 per cent for Hungarian firms. The smaller, newer Hungarian enterprises scored especially low on these questions. The follow up query, "Does your company respond to the following challenges?", sheds further light on these Hungarian greenfield businesses, which returned the lowest scores of all categories in half of the responses listed. Of particular importance is the fact that only 33.3 per cent of Hungarian greenfield sites plan any sort of product development (compared to a Hungarian average of 55.1 per cent and a foreign-owned average 75 per cent), and only 22.2 per cent plan a $\mathrm{R}$ and $\mathrm{D}$ co-operation with other firms (again, it is exactly the smaller firms which stand the most to gain from 
such ventures). Here also, foreign-owned firms reported higher scores (on average 50.0 per cent versus 40.8 percent), with particularly wide gaps being observed in responses such as increased outsourcing and product development. Of note is the fact that more Hungarian firms (61.2 per cent) plan to intensify internal $\mathrm{R} \& \mathrm{D}$, compared to the foreign-owned firms (54.2 per cent). See Table 3.

It is worth noting that the relatively heavier reliance of foreign-owned firms on outsourcing, one should keep in mind that this is an example of a practice which often makes more sense in the matured market economies than it does in the emerging market economies in the CEE. It originally arose in high wage countries as a result of significant wage gaps between core production workers and peripheral support staff. By outsourcing non-essential support functions, firms could save money and utilize more flexibility. However, in Hungary and other CEE countries, there are no significant wage differences to be found between direct and indirect production personnel (wages are generally uniformly low), and therefore, savings possibilities are lessened. The main reason for the reliance on outsourcing in Hungary has to do with flexibility.

\subsection{Research/Development and Firms' Innovation Profiles}

Questions regarding firms' individual and collaborative research and innovation efforts also reveal sizable rifts between Hungarian and foreign-owned companies. The biggest difference noted is not in absolute $R \& D$ expenditures, but rather in R\&D expenditures as a proportion of turnover. Here, foreignowned firms spent on average 0.21 per cent, compared to 2.06 per cent for Hungarian firms. It must be noted that all these figures are very small in the international context. (See Table 4)

One reason for Hungary's very low R\&D profile is simply the general contraction which has taken place in the economy since the collapse of the statesocialist political-economic regime, with the myriad of effects this has had on firms reliant on domestic market. All too often, in Hungary and as in most other countries, "luxuries" such as R\&D spending are the first to be sacrificed when companies are faced with tough times. Generally, foreign firms which have set up manufacturing operations in Hungary and other post-socialist countries of CEE are interested not so much in the capacities of Hungarian scientists and engineers, but rather, in the generally inexpensive across-the-board labour costs. This is perfectly understandable, as they may already possess sufficient intellectual capital to produce and market successfully.

As mentioned previously, there are temporal considerations at play here, too, however. Foreign managers who originally came with the sole intention of assembling products have slowly begun to notice that not only are Hungarian workers very capable of more flexible and diligent performance than workers in the home country (such observations, for example, have been made by managers 
at Audi, NOKIA, General Electric, etc.) but also that there is a great deal of untapped intellectual capital. Thus, we see the first signs of foreign companies moving their research facilities to be closer to their production facilities.

Table 4: Research and Development Profiles

\begin{tabular}{|c|c|c|c|c|c|c|c|}
\hline & $\begin{array}{c}\text { R\&D } \\
\text { expend. } \\
1990 \text { (in } \\
1000 \text { ECU) }\end{array}$ & $\begin{array}{c}\text { R\&D } \\
\text { expend. } \\
1995 \text { (in } \\
1000 \text { ECU) }\end{array}$ & $\%$ & $\begin{array}{c}\text { R\&D as } \\
1995 \\
\text { turnover }\end{array}$ & $\begin{array}{c}\text { R\&D staff, } \\
1995\end{array}$ & $\begin{array}{l}\% \text { of total } \\
\text { staff }\end{array}$ & $\begin{array}{c}\text { Planning } \\
\text { to expand } \\
\text { R\&D }\end{array}$ \\
\hline \multicolumn{8}{|c|}{ Hungarian Firms } \\
\hline $\begin{array}{l}\text { Privately } \\
\text { owned }\end{array}$ & 22.9 & 36.7 & 160 & $2.48 \%$ & 1.59 & 7.55 & $33.3 \%$ \\
\hline $\begin{array}{l}\text { Private/Stat } \\
\text { e ownership }\end{array}$ & 5.0 & 0.71 & 14.3 & $0.14 \%$ & 0.14 & 0.01 & $14.3 \%$ \\
\hline State owned & 46.8 & 80.0 & 171 & $1.33 \%$ & 12.57 & 0.87 & $28.6 \%$ \\
\hline $\begin{array}{l}\text { Greenfield } \\
\text { site }\end{array}$ & -- & 0.0 & -- & $0.00 \%$ & 0.25 & 1.76 & $25.0 \%$ \\
\hline $\begin{array}{l}\text { Brownfield } \\
\text { site }\end{array}$ & 20.43 & 53.95 & 181 & $2.50 \%$ & 5.78 & $6.00 \%$ & $30.6 \%$ \\
\hline Total & 29.43 & 38.95 & 132 & 2.06 & 3.14 & 5.06 & $29.5 \%$ \\
\hline \multicolumn{8}{|c|}{ Foreign Firms } \\
\hline $\begin{array}{l}\text { Greenfield } \\
\text { site }\end{array}$ & -- & 6.25 & -- & 0.24 & 2.00 & 0.43 & $15.8 \%$ \\
\hline $\begin{array}{l}\text { Brownfield } \\
\text { site }\end{array}$ & 133.3 & 42.67 & 32.0 & 0.09 & -- & -- & $25.5 \%$ \\
\hline Total & 133.3 & 38.95 & 29.2 & 0.21 & 3.30 & 0.56 & $20.0 \%$ \\
\hline
\end{tabular}

Source; Makó-Ellingstad-Kuczi, 1997: 16.

Especially dramatic differences are noticed as to the location of main customers, suppliers and consultants between Hungarian and foreign-owned firms. See in detail Table 5.

On average, customers were located in the region and nation for a combined total of 155.6 per cent for Hungarian firms, compared to combined total of 117.2 per cent for foreign-owned firms. Differences are even more striking when looking at the arguably more important location of suppliers; and here Hungarian firms rated a regional/national combined total of 133.3 per cent, compared to a mere 73.9 per cent for foreign-owned firms. Concurrently, foreign-owned firms rely on foreign partners for main customers and suppliers much heavier than Hungarian firms. Differences in the consultants category, where foreign-owned firms rely overwhelmingly on foreign-consultants (104.4 per cent to 15.5 per cent for Hungarian firms), can be ascribed to both the more 
expensive nature of international consultancies, as well as company-wide relations built up with a given set of international consultant networks.

Table 5: Location of Firms' Customers, Suppliers and Consultants

\begin{tabular}{|l|c|c|}
\hline $\begin{array}{c}\text { Location of the main } \\
\text { partner }\end{array}$ & Hungarian-owned firms & Foreign-owned firms \\
\hline Customer - Region & $80.0 \%$ & $52.2 \%$ \\
\hline Customer - Nation & $75.6 \%$ & $65.2 \%$ \\
\hline Customer - EU & $37.8 \%$ & $73.9 \%$ \\
\hline $\begin{array}{l}\text { Customer - Rest of } \\
\text { World }\end{array}$ & $22.2 \%$ & $26.1 \%$ \\
\hline Suppliers - Region & $64.4 \%$ & $34.8 \%$ \\
\hline Suppliers - Nation & $68.9 \%$ & $39.1 \%$ \\
\hline Suppliers - EU & $44.4 \%$ & $73.9 \%$ \\
\hline $\begin{array}{l}\text { Suppliers - Rest of } \\
\text { World }\end{array}$ & $24.4 \%$ & $21.7 \%$ \\
\hline Consultants - Region & $22.2 \%$ & $13.0 \%$ \\
\hline Consultants - Nation & $37.8 \%$ & $39.1 \%$ \\
\hline Consultants - EU & $13.3 \%$ & $69.6 \%$ \\
\hline $\begin{array}{l}\text { Consultants - Rest of } \\
\text { world }\end{array}$ & $2.2 \%$ & $34.8 \%$ \\
\hline
\end{tabular}

Source: Makó-Ellingstad-Kuczi, 1997: 19.

\subsection{Diffusion of 'leading edge' managerial practices in the region}

The REGIS Project survey was carried out with managers interviewed given a list of organizational tools from 'leading-edge' concepts in management and asked which their company had introduced. There were some rather dramatic divergences between foreign-owned and Hungarian firms. However, before we examine these, a short rhetorical detour is needed. When interpreting responses to questions such as "Have you introduced TQM, Just-in-Time, Information Technology (IT), benchmarking, etc.?," we must also consider the possibility of unfamiliarity with the slang. At the core of some of these more fashionable concepts bandied about by the business press and western management consultants are to be found, very often, some very elementary ideas which one does not need to read the Harvard Business Revue to be familiar with. A Hungarian manager might reply "no, we haven't instituted an IT system yet," while sitting at a desk with an integrated network computer. 
Total Quality Management (TQM), for example, prescribes a set of procedures and a corporate mentality designed to make quality a given at every stage in the production and distribution process. While helpful in focusing attention on quality, it would be folly to suggest that a formalised TQM system is a prerequisite for higher quality. Group work found favour in the western business community after successful patterns were observed in Japanese and Swedish workplace practices. It is a little known fact, for example, that formalized group work initiatives (with their own cost accounting structure and extremely flexible use of manpower and skill, creating in effect, firm-internal profit centres) were institutionalised in Hungary at the early 1970's; these were the so-called 'Economic Working Associations' (VGMK) (Stark, 1985., Makó-Simonyi, 1992.) Furthermore, the 'faddish' and occasionally temporary nature of some of the above-listed organizational tools or managerial concepts cause us to wonder if their implementation or lack thereof is indeed a proper measure of managerial finesse. A study cited by the Financial Times comes to mind which revealed that British firms which had adopted JIT inventory control procedures had twice the rate of bankruptcy as "traditional" firms.

Table 6: Diffusion of Organizational Innovations in Regis Project Firms

\begin{tabular}{|l|c|c|c|}
\hline \multicolumn{1}{|c|}{$\begin{array}{c}\text { Forms of Organizational } \\
\text { Innovation }\end{array}$} & $\begin{array}{c}\text { Hungarian- } \\
\text { owned firms }\end{array}$ & $\begin{array}{c}\text { Foreign- } \\
\text { owned firms }\end{array}$ & $\begin{array}{c}\text { Other Regis } \\
\text { Project region's } \\
\text { firms }\end{array}$ \\
\hline Total Quality Management & $18.4 \%$ & $37.5 \%$ & $46.3 \%$ \\
\hline Group Work & $55.1 \%$ & $66.7 \%$ & 47.85 \\
\hline Profit or cost centers & $44.9 \%$ & $62.5 \%$ & $32.7 \%$ \\
\hline Inter-organizational networking & $34.7 \%$ & $37.5 \%$ & $20.0 \%$ \\
\hline Benchmarking & $4.1 \%$ & $37.5 \%$ & $24.7 \%$ \\
\hline Flat hierarchies & $22.4 \%$ & $50.0 \%$ & $39.5 \%$ \\
\hline Interdisciplinary design teams & $18.4 \%$ & $33.3 \%$ & $22.2 \%$ \\
\hline Just-in-Time delivery(JIT) & $10.2 \%$ & $41.7 \%$ & $37.7 \%$ \\
\hline Outsourcing & $8.2 \%$ & $29.2 \%$ & $22.2 \%$ \\
\hline System suppliers & $10.2 \%$ & $20.8 \%$ & n.d. \\
\hline ISO 9000 & $34.7 \%$ & $62.5 \%$ & $52.0 \%$ \\
\hline Information technology (IT) & $28.6 \%$ & $70.8 \%$ & $44.5 \%$ \\
\hline Average scores & $24.1 \%$ & $45.8 \%$ & $35.4 \%$ \\
\hline
\end{tabular}

Source: Makó-Ellingstad-Kuczi (1997:12.), Cooke, et all. (1998:14.)

This said, the responses given to such questions can indeed be used as a useful tool interpreting managerial priorities, as well as the dominant models (and 
sources of inspiration), present at firms in the region surveyed. Looking at the responses to all questions, foreign-owned companies returned average scores of 45.8 per cent compared to 24.1 per cent for Hungarian firms. Particularly large differences are visible under TQM, Profit Centers, Benchmarking (ironic, as Hungarian and other CEE firms in the period of socialism generally worked under norms for decades), Flat hierarchies, Outsourcing, ISO, JIT and IT. Table 6 compares the results concerning firms operating in the Székesfehérvár region (Hungarian firms versus foreign-owned firms) to the integrated data of other region's firms located in the other Regis Project countries.

\section{Weak Multiplier Effects of FDI: Input and Output Profiles of the Firms in Székesfehérvár region}

The product input and output profiles of firms operating in the Székesfehérvár region are important when considering not only individual firm success (dynamic, successful companies tend to have a stronger than average output or export profile), but the shape and intensity of a wide range of existing and emerging regional networks. Firms which utilise the region for only a small portion of their product inputs are unlikely to have a strong interest in helping develop a regionally-based set of institutions which promote inter-firm or public-private co-operation.

One of the strongest, most significant set of differences between ownership nationality categories visible in the REGIS Project survey has to do with the input/output (or import/export) profiles exhibited. Managers were asked to give percentage scores for product inputs and output, differentiated by the Székesfehérvár region, Hungary, European Union, and finally, the rest of the world. Foreign-owned firms, especially foreign-owned greenfield sites, report using very few Hungarian inputs (either components or raw materials) in the production process. On average, foreign-owned firms rely on the region for only 9.3 per cent, and on the nation for only 21.8 per cent of product inputs. Together, this gives a domestic content ratio of 31.1 per cent (only 22.2 percent in the case of greenfield sites). By contrast, and not surprisingly, Hungarian firms demonstrate far heavier reliance on domestic component producers. Hungarian firms on average rely on the region for 27.8 per cent, and on the nation for 46.4 per cent of product inputs, yielding a domestic content ratio of 74.2 per cent (83.3 per cent in the case of state-owned firms). See Table 7 .

In accounting for such large gulfs, one must consider that a great many greenfield sites were offered "off-shore" status, which grants duty-free importation of production components. Hungarian firms, and foreign-owned brownfield sites are generally not granted duty-free importation allowances. "Off-shore" status creates a very powerful disincentive to search for regional or national supplier networks, especially as many of these firms have an already existing European or world-wide supplier network. (When queried as to why 
domestic content rates are so low, many foreign managers cite the lack of contacts among potential Hungarian firms, as well as quality concerns. According to another study, carried out in the same period as the REGIS Project (1996-1997), out of the quality and flexibility concern, the most unfavourable features of the Hungarian suppliers concerned the 'timely delivery' and 'reliability'. Akar, 1997:6.)

Table 7: Product Inputs of the Firms : Székesfehér region

\begin{tabular}{|l|c|c|c|c|}
\hline & Region & Hungary & EU & $\begin{array}{c}\text { Rest of } \\
\text { World }\end{array}$ \\
\hline Hungarian Firms & \multicolumn{5}{|l|}{} \\
\hline Privately owned & $25.9 \%$ & $44.7 \%$ & $16.0 \%$ & $6.9 \%$ \\
\hline Private/State ownership & $31.0 \%$ & $55.1 \%$ & $1.4 \%$ & $0.0 \%$ \\
\hline State owned & $33.9 \%$ & $49.4 \%$ & $14.8 \%$ & $1.9 \%$ \\
\hline Greenfield site & $30.3 \%$ & $29.2 \%$ & $13.8 \%$ & $4.4 \%$ \\
\hline Brownfield site & $27.2 \%$ & $50.3 \%$ & $15.1 \%$ & $4.9 \%$ \\
\hline Total & $27.8 \%$ & $46.4 \%$ & $14.8 \%$ & $4.8 \%$ \\
\hline Foreign Firms & $7.1 \%$ & $15.1 \%$ & $63.5 \%$ & $14.5 \%$ \\
\hline Greenfield site & $22.5 \%$ & $54.3 \%$ & $20.8 \%$ & $2.5 \%$ \\
\hline Brownfield site & $9.3 \%$ & $21.8 \%$ & $54.9 \%$ & 14.0 \\
\hline Total
\end{tabular}

Source: Makó-Ellingstad-Kuczi, 1997:7.

Such a heavy reliance on imported components does come with a price, however. Logistical concerns having to do with on-time delivery of components (especially when one considers that 41.7 per cent of foreign-firms and 44.4 per cent of foreign-owned greenfield companies rely on Just-in-Time inventory control systems) consistently rank as one of the biggest problems facing mangers at foreign-owned greenfield sites. (The reliance of the greenfield sites on JIT inventory control system especially high (55 per cent) in the automobile sectors' firms in the region surveyed.)

Multiplier effects are notoriously vague and difficult to quantify, but it is obvious that such a heavy reliance on imported components (often those with the highest value-added), makes any such effects in the Székesfehérvár region, and Hungary as a whole, relatively modest. From the perspective of innovation, technological diffusion from high-tech, greenfield plants to domestic producers is severely limited by the heavy reliance on imported components or on their 
own suppliers already operating in Hungary. From the ecological standpoint, such a situation is not without objections, as the distances imported components travel (most often by lorry) are much greater than domestic components.

It must be added, the temporal components associated with FDI flows should also be considered, and even at this early point in time, it is evident that the above-listed characteristics are beginning to change for the better. Networks whether for supply, research and development, or distribution - do not arise spontaneously. As foreign-owned companies accumulate positive experiences manufacturing in Hungary, it is hoped they will gradually begin to expand local production beyond low value-added assembly operations. Audi, GE and Nokia, for example, have begun to move some research and development facilities to Hungary to be closer to their production sites, and a number of foreign-owned companies have begun making the first moves towards building a local supplier network. Ford, for instance, is to locate a Central European components buying center in Hungary in the next years, following GM's lead of opening the same type of facility in Poland.

Perhaps not surprisingly, given the above-listed figures, there is also a wide gulf in product outputs (exports), with Hungarian-owned firms relying heavily on the domestic market, and foreign-owned firms (again, greenfield firms in particular) being especially active exporters. Hungarian-owned firms export, on average, only 15.6 per cent of output, with state-owned firms being the strongest exporters, while foreign-owned firms export a dramatic 54.5 per cent (61.6 per cent for greenfield sites). See Table 8.

Table 8: Product Output of Firms operating in Székesfehérvár Region

\begin{tabular}{|l|c|c|c|c|}
\hline & Region & Hungary & EU & $\begin{array}{c}\text { Rest of } \\
\text { World }\end{array}$ \\
\hline Hungarian Firms & \multicolumn{5}{|l|}{} \\
\hline Privately owned & $47.2 \%$ & $40.5 \%$ & $8.6 \%$ & $3.7 \%$ \\
\hline Private/State ownership & $56.8 \%$ & $34.0 \%$ & $9.3 \%$ & $0.0 \%$ \\
\hline State owned & $36.4 \%$ & $39.2 \%$ & $5.9 \%$ & $18.4 \%$ \\
\hline Greenfield site & $58.1 \%$ & $37.5 \%$ & $3.8 \%$ & $0.6 \%$ \\
\hline Brownfield site & $43.4 \%$ & $38.9 \%$ & $11.0 \%$ & $6.8 \%$ \\
\hline Total & $45.8 \%$ & $38.7 \%$ & $9.8 \%$ & $5.8 \%$ \\
\hline Foreign Firms & $15.7 \%$ & $22.8 \%$ & $49.6 \%$ & $12.0 \%$ \\
\hline Greenfield site & $30.0 \%$ & $47.3 \%$ & $16.3 \%$ & $6.5 \%$ \\
\hline Brownfield site & $16.7 \%$ & $25.0 \%$ & $43.7 \%$ & $10.8 \%$ \\
\hline Total
\end{tabular}

Source:Makó-Ellingstad-Kuczi, 1997:9. 
Three observations need to be made about the survey findings regarding patterns of output or export. Firstly, is the overwhelming dominance of the EU as an export target, which while having much to do with geographic proximity and buying power, also is affected by the EU's trading regime which gives products coming from the CEE countries slightly preferential tariff status (as a result of Association Agreements). To qualify for such preferential tariffs, the products must have a domestic and/or European Union content of over 50 per cent. Many foreign-owned greenfield sites (as well as, for example, nearly all automobile manufacturers present in Hungary) qualify for preferential tariffs based on European Union, not domestic, content.

Secondly, one notices the marked collapse of any strong alternative market for Hungarian exporters. Less than ten years ago, the Soviet Union and CMEA trading bloc was the destination of the majority of Hungarian exports. The lapse of the ruble-based trading system, the collapse of buying power of consumers in these countries, as well as the very pronounced political guidance towards western markets has hurt Hungarian producers which relied on the CMEA markets.

Thirdly, and perhaps most importantly, one must be aware of the weakness of the domestic market. Consumer buying power and real wages have dropped sharply since 1989 (with a 15 per cent drop in real earning registered in the middle of 1990's), which has hurt Hungarian companies, which by size and tradition tend to be domestically focused, much more than foreign-owned companies. While slow improvement in buying power, and a general stabilization of macro-economic indicators will have a positive effect on all sectors of the economy, this will be an especially welcome development for the Hungarian small and medium sized firms.

In relation to the composition and locations of suppliers-customers, it is worth noting the following tendencies. When asked if their company is supplying one or a few dominant suppliers, 66.0 per cent of mangers at Hungarian-owned companies replying "yes", as compared with 76.9 per cent at foreign-owned firms (85.0 per cent at foreign-owned greenfield sites). The follow-up question, which asked what share of sales goes to the most important customer, reveals 32.4 per cent at Hungarian-owned companies and 56.8 per cent at foreign-owned companies. The relatively greater dependence of foreign-owned companies on one or a few customers may be at least partially accounted for by the fact that many of the foreign-owned greenfield operations are often processors, producers or assemblers for their company's own world-wide production chain (i.e., there is a noticeable lack of on-site integrated processes at the foreign-owned greenfield plants, as it is part of company-wide vertically-integrated production process.)

Parallel to input/output or import/export profiles are the locations of primary competitors. Foreign-owned companies viewed the European Union or the rest 
of the world as the location for a score of 100 per cent, compared to 60 per cent for the region and Hungary. By contrast, Hungarian-owned firms saw gave a combined external score of 41.7 per cent, and 112.5 per cent for the region and Hungary. It is apparent that Hungarian and foreign-owned firms have significantly different geographical horizons.

\section{Conclusions}

This paper aimed to provide perspective on various possibilities and limitation of Foreign Direct Investments to serve as the engine of modernisation in the Hungarian economy. The focus in our investigation was the firm, which is a key institution in re-organizing economic activities in the emerging market economies of Central and Eastern Europe. In the focus of our investigation was the 'absorptive capacity' of the regional or national economy or in other word degree of integration of the Hungarian firms in the global economy.

Lessons from the survey in the region which has attracted the highest concentration of FDI in Hungary could be summarized in these ways. First, the types of ownership of the firms (e.g., Hungarian owned versus foreign owned, greenfield versus brownfield sites, etc.) serve as strong proxy variables for the degrees of competitiveness and the innovation capacities of the companies.

Second, the multiplier effects normally associated with manufacturing facilities (many of which are high-tech and produce high value-added products) are largely missing from the Hungarian environment.

Third, there is a surprisingly large gap between Hungarian owned and foreignowned firms in the following fields: competitive strength, innovation capacities, customers-suppliers relations and product input/output profiles.

Fourth, the Hungarian small and medium sized firms - or the Hungarian greenfield plants - show a strong tendency towards technological, product and process stagnation in comparison with the foreign-owned firms. In addition to spending almost nothing on R\&D projects, not one Hungarian greenfield plant reporting participation in any kind of technology/innovation/training supporting programs.

Fifth, the Hungarian small and medium sized firms have particularly weak innovation networks. Especially, Hungarian 'greenfield' plants characterized by the absence of formalized partner institutions (e.g. government agency, subsidy providers, university etc.)

Finally, according to the experiences of the regional survey, the major sources of innovation (both product and process) are customers and suppliers. This finding underscores the point why it is so important for Hungarian firms to become a more active part of the component supply networks of the technologically advanced foreign-owned firms operating in the country. 
Evaluating the role played by foreign-owned firms on the technological development of host country is rather ambiguous. Technological development of the country (region) concerned involves organizational innovation/modernizing management methods. This type of technological development improves, upgrades of mastering the operational procedures or the 'know-how' of a given technology. (Lall, 1993:125), that is MNCs “... transmit state-of-the-art knowledge, and provide skill and equipment to make it operational," but in the region surveyed even this beneficiary effects were rather sporadic due to the weak multiplier effects.

Data on R\&D activities clearly illustrated that until now the MNCs operating in the region have not become involved deeper in indigenous research or in development of 'know-why' activities. Summing up our results, we may those authors who (e.g. Martin, 1998) are using the categories of Gordon (1996) on the logics of 'internationalisation', 'multinatinationalisation' and 'globalization' that the CEE countries participation in the multi-national world production system is rather limited at this moment.

\section{References}

Adorján, M. - Balaton, K. - Galgóczi, B. - Makó, Cs. - Ternovszky, F. (1996) 'Gazdasági szervezetek az átalakulás időszakában’, Vezetéstudomány, 7 - 8. sz. , pp. 5-25.

Árva, L. (1994) 'Direct Foreign Investment: some theoretical and practical issues', Budapest: National Bank of Hungary - Workshop Studies, No.1.

Árva, L. (1997) 'Külföldi müködőtőke, hazai beszállítói kapcsolatok, külkereskedelmi mérleg és technológiatranszfer’, Közgazdasági Szemle, XLIV. Évf., november, 1007-1018.

Borish, M.S. - Noel, M. (1996) 'Private Sector Development During Transition', (Visegrad countries), Washington D. C. : Word Bank Discussion Paper, No. 318.

Carson, J. (1998) 'Manufacturing Survey', (The World as a single machine), The Economist, June $20^{\text {th }}$, pp. 3-20.

Child, J. - Czeglédy, A. (1996) 'Managerial Learning in the Transformation of Eastern Europe: Some Key Issues’, Organisation Studies, 17/2., pp. 167-79.

Child, J. - Markóczy, L. (1993) 'Host-country managerial behaviour and learning in Chinese and Hungarian joint-ventures', Journal of Management Studies, 30/4: 611-31.

Cooke, Ph. (1008) 'Regional Innovation Systems: Designing for the Future', Final Report, European Community, DGXII-TSER, May, p. 192.

Cooke, Ph.-Boekholt, P. -Tödtling, F. (1998) 'Regional Innovation Systems: Designing for the Fure', Final Report, EU Commission, DG12-TSER, May, ISBN-1-899-184236, p. 192.

Cséfalvay, Z. (1993) 'Felharmadolt ország', (Magyarország területi átrendeződése), Budapest: Magyar Nemzeti Bank 
Ellingstad, M. (1996) 'Hungarian Industrial Relations in Transition', (An Examination of Greenfield Investment and Privatization on the Labour Market and its Institutions), Szeged: JATE Department of Sociology - Minneapolis: La Follette Institute University of Wisconsin

Enese Lieb-Dóczy (1997) Acquisition and the Transformation Process, (A Comparative Case Studies from Eastern Germany and Hungary), Warwick: Department of Economics University of Warwick, (Unpublished Ph.D. Disseertation)

Gordon, R. (1996) 'Globalization, New Production Systems and the Spatial Division of Labour, (in) Littek, W.-Charles, A. (eds.), The New Division of Labour: Emerging Forms of Work Organization in International Perspective, New-York-Berlin: Walter de Gruyter

Green, P. S. (1998) 'Eastern Europe as an Opportunity for Aggressive Investors', International Herald Tribune, April 25-26., p.17.

Hámori, Sz. (1996) ‘Tovább csökken a foglalkoztatás', Népszabadság, december 10., p. 1 and 10.

Heti Világgazdaság (1998) ‘Versenyképességi rangsor', 18.sz., május 8. P. 33.

Ishikawa, A. (1998) 'Organization and Activity of Trade Unions in Central and Eastern Europe', Occasional Papers on Changes in the Slavic-Eurasian World, No.65., Slavic Research Center, Hokkaido University, March, Sapporo, p. 45.

Kasahara, K. (1997) 'Firm Level Skill Formation and Career of Management Class during Transformation Process in Poland', Yamamura, R. (ed.) Occasional Papers on Changes in the Slavic-Eurasian World, No. 22., Slavic Research Center - Hokkaido University, March, Sapporo, p. 55.

Kornai, J. (1996) 'Kiigazítás recesszió nélkül', Közgazdasági Szemle, XLIII. július augusztus, pp. 585-613.

Lall, S. (1993) 'Multinationals and Developing Countries: Some Issues for Research', (in) Eden, L.-Potter, E.H. (eds.) Multinationals in the Global Political Economy, London: The Macmillan Press Ltd. , pp. 122-128.

Makó, Cs. - Ellingstad, M. - Kuczi, T. (1997) 'Regional Innovation System (REGIS): Székesfehérvár Region Survey Results and Interpretation', Budapest: Institute for Social Conflict Research, Hungarian Academy of Sciences, January, p. 33.

Martin, R. (1998) 'Central and Eastern Europe and the International Economy: the Limits to Globalisation', Europe-Asia Studies, Vol. 50. No. 1. Pp. 7-26.

Marsh, P. (1996) 'Car Components: Germany lags UK and Japan in quality', The Financial Times, November 7.

Népszabadság (1996) 'A külföldi tőke fele az államé lett', november 6. P. 1 and 1ö.

Népszabadság (1998.a.) 'A sztrádák mentén terjeszkednek a multik', április 28.

Népszabadság (1998.b.) ‘A külföldi tőke Magyarországon', (Osztrák értékelés a befektetésekről), május 30. P. 14.

Simon, L. - Davies, G. (1996) 'A Contextual Approach to Management Learning: the Hungarian Case', Organisational Studies, Vol. 17. Issue 2., pp. 227-47. 
Soulsby, A. - Clark, E. (1996) 'The Emergence of Post-Communist Management in the Czech Republic', Organisational Studies, Vol. 17. Issue 2. Pp. 227-47.

Stark, D. (1996) 'Hálózati tõkések', (Posztszocialista tulajdon-átalakulás), Figyelõ, XL. Évf. május 9. Pp. 44-45.

Szelényi, I. (1996) 'A posztszocialista társadalom szerkezetének változásai’, (A menedzseri hatalom elméletének újragondolása), Magyar Tudomány, No. 4. Pp. 385-402.

Tóth, I.J. (1998) 'Vállalkozások tulajdonosi kapcsolatai Magyarországon 1992-1996 között', Közgazdasági Szemle, XLV. Évf. június, pp. 591- 615.

Tóth, Á. (1998.c.) 'A csábítás ára', (Székesfehérvár és a multik vitája adókról és kedvezményekrõl), Népszabadság, június 20. P. 30..

Yamamura, R. - Ishikawa, A. - Makó, Cs. - Ellingstad, M. (1996) 'Business Organisation in the Transformation Process in the Post-Socialist Countries', Sapporo: Hokkaido University - Slavic Research Center, (Preliminary Research Report), p. 25.

Whitley, R. - Czabán, L. (1998) 'Ownership, Control and Authority in Emergent Capitalism: Changing Supervisory Relations in Hungarian Industry', The International Journal of Human Resource Management, 9:1, February, pp. 99-115. 